\title{
Displaying Science in Context at the Royal Institution of Great Britain
}

Frank A.J.L. James

Department of Science and Technology Studies, University College London.

Address for correspondence: Royal Institution, 21 Albemarle Street, London, W1S 4BS.

fjames@ri.ac.uk

There can be few buildings in the world with a floor area of around 3000 square metres where so many chemical and scientific discoveries have been made than the Royal Institution. Located behind its Corinthian columned façade (figure 1), erected in the 1830s and dominating the northern end of Albemarle Street in the Mayfair district of London, the laboratories of the Royal Institution have been there since shortly after its foundation in 1799 . In this building figures such as Humphry Davy, Michael Faraday, John Tyndall, James Dewar, William Bragg, Lawrence Bragg, and, more recently, George Porter have lived, researched and lectured. Furthermore, the Royal Institution has served as a model for other institutions around the world, most notably the Smithsonian Institution in Washington. James Smithson (1764-1829) was an early Proprietor of the Royal Institution and he seems to have its aims in mind when he drew up his will.

Because of the significance of its heritage, the Royal Institution has a modern display, occupying most of the lower ground floor, of many original pieces of apparatus and chemical samples - including the first specimen of benzene made by Faraday in 1825 . One of the heritage strengths of the Royal Institution is that every object, sample, manuscript, book, image and so on was created or purchased for use in the building and has been retained on site ever since. This is what distinguishes the Royal Institution from those museums that display important and significant scientific objects, but where they are necessarily separated from the original context of their creation and use. Furthermore, many of the objects displayed on the Royal Institution, such as Davy's miners' safety lamp (figure 2), Faraday's electro-magnetic induction ring, or the first model of lysozyme, count as among the most iconic pieces of scientific apparatus ever made. They are on par with Galileo's telescope in the Museo Galileo, Florence, or Newton's reflecting telescope in the Royal Society, London. 
While it might seem strange to modern eyes that the Royal Institution continues to exist in the midst of one of the most fashionable and wealthy areas of London, in the nineteenth century it was one of a number of scientific institutions in the district. At the time of the its foundation the Board of Agriculture (where Davy lectured on agricultural chemistry for ten years) was in Sackville Street a couple of blocks to the east. By the middle of the century the Royal College of Chemistry was located to the north in Oxford Street, while to the south were the School of Mines and the Geological Museum in Jermyn Street. These institutions later moved to South Kensington to form the core of Imperial College and part of the Natural History Museum. To the east was and is Burlington House, home to many of the leading learned scientific societies.

The Royal Institution was formally founded at a meeting held on 7 March 1799, at 32 Soho Square, the London house of the President of the Royal Society, Joseph Banks (17431820). Its founding took place against the background of the war with France (then in its sixth year) and the increasing industrialisation that had occurred in Britain during the preceding century. The war, which would continue for a further sixteen years, meant that Britain had restricted access to Continental markets and was forced to rely on its own resources. To help overcome this problem, it was initially envisaged that the Royal Institution would provide access to scientific and technical knowledge, through lectures, to a largely aristocratic and upper middle class audience with the aim of applying that knowledge for practical purposes. Furthermore, it was seen as a place where scientific knowledge could be practically applied to agricultural improvement, industrialisation, and the consolidation of the Empire, the latter a particularly important consideration for Banks. These aims, in turn, encouraged those who had such interests to join: the early membership of the Royal Institution shows a strong presence of large land owners, military men, and those who worked in the colonial service such as the East India Company.

At the initial meeting in Banks's house, a list of fifty-eight names was read of gentlemen who had agreed to contribute fifty guineas* each to be a Proprietor of a new Institution For diffusing the Knowledge, and facilitating the general Introduction, of Useful Mechanical Inventions and Improvements; and for teaching, by Courses of Philosophical Lectures and Experiments, the application of Science to the common Purposes of Life.

\footnotetext{
* A guinea was 21 shillings, while a pound was 20 shillings.
} 
These aims were in contrast to those of the Royal Society, the meetings of which were restricted to their Fellows and their few guests to hear learned papers. Furthermore, the Royal Society did not have a laboratory, which would be a central feature of the Royal Institution. Banks, who generally opposed the forming of new scientific bodies, actively supported the establishment of the Royal Institution to do things that were not deemed appropriate to the Royal Society.

During the summer of 1799 the Royal Institution acquired 21 Albemarle Street, where it remains. Originally a townhouse that had been constructed in stages during the eighteenth century, much construction work was required to convert it into a scientific institution with lecture rooms, laboratories, display areas, libraries, offices, etc. Nevertheless, just over a year after its founding the first Professor of Chemistry, Thomas Garnett (1766-1802), delivered on 11 March 1800 the first of what now exceeds 60,000 lectures to have been given in the Royal Institution. Following tensions within the Royal Institution Garnett resigned in June 1801 and was replaced by Thomas Young (1773-1829), who by all accounts was not a particularly effective lecturer.

Young had developed an early form of the wave theory of light that incurred the displeasure of the radical Whig lawyer and politician Henry Peter Brougham (1778-1868). In his review of one of Young's papers that had been read to the Royal Society, Brougham attacked both Young and what he took to be the lack of seriousness in the audience of the Royal Institution, especially owing to the presence of women at lectures:

We demand, if the world of science, which Newton once illuminated, is to be as changeable in its modes, as the world of taste, which is directed by the nod of a silly woman, or a pampered fop? Has the Royal Society degraded its publications into bulletins of news and fashionable theories for the ladies who attend the Royal Institution?

Brougham missed the point since, unlike the Royal Society which did not admit women to its Fellowship until 1945, the Royal Institution from its inception was intended for women as well as for men.

One of the sources of tension at the Royal Institution was the appointment in February 1801, of the twenty-two-year-old Humphry Davy (1778-1829) as lecturer in chemistry whom Garnett clearly saw as a rival. Davy, born in Penzance, the son of a woodcutter, was by the end of the 1790s working in the Medical Pneumatic Institution in Bristol, run by Thomas Beddoes (1760-1808). The Medical Pneumatic Institution had been funded by subscriptions, some very generous, to support research into whether the new gases (or airs as they were 
called) discovered during the latter half of the eighteenth century had any therapeutic properties, especially in curing, or at least mitigating, consumption. Alas such expectations were not met, but Davy did discover the physiological action of nitrous oxide (laughing) gas. As well as working and writing on gases, Davy also undertook very early electrical researches following the announcement, right at the end of the eighteenth century, of the invention by Alessandro Volta (1745-1827) of what Davy would shortly call the electric battery. Such work made Davy's name in England and contributed significantly to his move to the Royal Institution. Evidence of the way he and laughing gas captured the public imagination can be found in the famous caricature by James Gillray (1757-1815) (figure 3). In it Garnett is portrayed administering the gas to the Royal Institution's Treasurer John Hippisley (1748-1825) with somewhat unfortunate results behind, while a slightly demonic Davy watches with a pair of bellows poised for further action.

In Davy the Royal Institution acquired an immensely popular lecturer who attracted large audiences, including women, who were particularly enamoured of him. Indeed, the readership of the famous Conversations on Chemistry (1806) by Jane Marcet (1769-1858) was precisely the same as Davy's audience at the Royal Institution. It was he who firmly established the Royal Institution as a popular venue for first-rate lectures.

But, in addition, and following on from his experiences at the Medical Pneumatic Institution, Davy also introduced the idea that the Royal Institution should undertake original scientific research, something that was never envisaged by its founders. During the first decade of the nineteenth century, Davy developed the first coherent theory of electrochemical action in the course of which he isolated the chemical elements sodium, potassium, barium, calcium, magnesium, and strontium, and he later showed, contra the French chemists, that chlorine and iodine were indeed elements.

In 1812 the Prince Regent (1762-1830) knighted Davy and three days later he married Jane Apreece (1780-1855), a wealthy widow who had attended his lectures. This allowed him to retire from his professorship at the age of thirty-four and he delivered his final course of lectures early that year. One of Davy's auditors for those lectures was a twenty-year old apprentice bookbinder with a strong interest in chemistry, Michael Faraday (1791-1867). Faraday, the son of a blacksmith who had moved from Westmorland to London in 1788, had a typical working-class education. The family belonged to the Sandemanians, a very small literalist sect of Christianity to which Faraday was fully committed throughout his life. The close connection between Faraday's religion and his scientific career can be summed up as his search for the laws of nature that God had written into the universe at the time of the 
Creation and the use of that knowledge for the betterment of humankind. To a large extent this accounts for Faraday's anti-materialistic views, for he had a strong antipathy to atoms.

During his apprenticeship Faraday had developed an overriding interest in science, particularly chemistry. He read many books on the subject, including Marcet's Conversations on Chemistry, and attended lectures in various places, including Davy's last course at the Royal Institution which dealt with a problem then at the cutting edge of chemistry, namely the definition of acidity. Faraday took detailed notes of the lectures, and sent them to Davy asking for a job in science at the Royal Institution. After a complex set of circumstances, Faraday was appointed Chemical Assistant at the Royal Institution in the spring of 1813. In 1821 he became Superintendent of the House, in 1825 Director of the Laboratory, and in 1833 Fullerian Professor of Chemistry, a post created especially for him by the eccentric philanthropist John Fuller (1757-1834).

Following the discovery of electro-magnetism in 1820 by the Danish savant Hans Christian Oersted (1777-1851), Faraday turned his attention to this subject. The following year he discovered electro-magnetic rotations, the principle behind the electric motor. Ten years later, in August 1831, he discovered electro-magnetic induction by, in effect, making the first transformer (figure 4). A few weeks later he made the first generator which produced electric current from the movement of a magnet in a coil of wire. (The originals of both these devices, together with many other pieces of Faraday's apparatus, are on permanent display in the Royal Institution). From the late nineteenth century onwards, the induction ring has been seen as the foundational object for electrical engineering. In 1931 enormous celebrations were held to mark the centenary of Faraday's discovery, including a fortnight long exhibition at the Royal Albert Hall and a grand commemorative meeting addressed by the Prime Minister, Ramsay MacDonald (1866-1937).

Later in the 1830s Faraday studied electro-chemistry, discovering his laws of electrolysis and developing with a number of classical scholars the nomenclature of electrochemistry (electrode, anode, cathode, ion, etc.), terms with which we are so familiar today. In 1836 Faraday built a twelve-foot cube covered in metal gauze (the first Faraday cage), in which he showed that electricity was a force rather than an imponderable fluid, as had been argued up to that time. In 1845 he demonstrated that light was affected by magnetism and that all matter possessed magnetic properties, not just iron. These experimental discoveries allowed him to formulate his field theory of electro-magnetism in which he argued that force, rather than matter, was the primary constituent of the universe. Later mathematised by his younger contemporaries William Thomson (Lord Kelvin, 1824-1907) and James Clerk 
Maxwell (1831-1879), field theory became, and remains, one of the cornerstones of modern physics.

Faraday also succeeded Davy as the most attractive and engaging lecturer in the middle third of the nineteenth century. In the Royal Institution's Christmas Lectures for young people, established in the mid-1820s, Faraday delivered nineteen series. These included his famous Chemical History of a Candle which he thrice gave in 1848-1849, 18541855 and again in 1860-1861. In 1861 the lectures were published and became a highly successful book which has never been out of print in English subsequently. The book has also been translated into several languages including Dutch, French, Polish, and Japanese.

Following Faraday's death in August 1867, John Tyndall (c.1822-1893) was appointed to most, but not all, of his positions in the Royal Institution. Tyndall, born in Ireland, was originally a railway surveyor. He then taught mathematics at Queenwood College in Hampshire, a boys' school, before going to Marburg where he studied under Robert Bunsen (1811-1899), receiving his doctorate in 1850. Tyndall took a strong interest in magnetism and thus attracted Faraday's attention. Despite their having significantly differing views on a whole range of scientific, social and ideological issues, Faraday was a strong supporter of Tyndall and in 1853 he secured Tyndall's appointment as Professor of Natural Philosophy at the Royal Institution.

Tyndall's scientific work included establishing a theory of glaciers, attacking theories of spontaneous generation and showing that the heat absorption properties of different gases varied by several orders of magnitude. From this Tyndall deduced the existence of the greenhouse effect (though he did not use that term) in the atmosphere caused by carbon dioxide. But his most notable work was in the popularisation of science. He delivered a large number of lectures (including twelve series of Christmas Lectures) and wrote many books on popular scientific subjects. He coined the phrase "the scientific use of the imagination" which Arthur Conan Doyle (1859-1930) had Sherlock Holmes use in The Hound of the Baskervilles (1902). In his Presidential address to the Belfast meeting of the British Association for the Advancement of Science in 1874, Tyndall made the most famous, not to say notorious, statement of his view that the world should be studied from a naturalistic viewpoint rather than a theistic one.

Research came to have an ever-increasing role within the Royal Institution as science in Britain expanded in the late nineteenth century. Following Tyndall's retirement in 1887, John William Strutt (Third Lord Rayleigh, 1842-1919), was appointed Professor of Natural Philosophy, while James Dewar (1842-1923), who had been Fullerian Professor of Chemistry 
since 1877, became Superintendent of the House. Rayleigh, who had moved from being Cavendish Professor of Experimental Physics at the University of Cambridge, was also a Secretary of the Royal Society and had a private laboratory at his house Terling Place.

Dewar's appointments in 1877 and 1887 led to mounting pressure on the utilization of the available laboratory space. Although he divided his time between Cambridge (where he was Jacksonian Professor of Experimental Natural Philosophy) and the Royal Institution, his important work on cryogenics was located at the Royal Institution. This required large-scale apparatus, particularly pumps, as he sought to reach ever lower temperatures artificially, to fulfill his long term goal of liquefying hydrogen. In the course of this research in 1892 he invented the Dewar flask (now popularly known as the 'Thermos' flask), as a container which by minimizing heat loss by conduction, convection and radiation, could hold liquid gases much longer than before.

By the end of the nineteenth century it was becoming increasingly clear that the practice of science would need to change considerably. In particular, scientific research needed to move from being undertaken by a single individual working in a laboratory, perhaps with an assistant, to the current situation where the head of a laboratory is generally supported by a large staff of postdoctoral assistants and research students. In part this change was driven by the expansion of scientific research throughout the world and the consequent demands for enormously large facilities compared to those of the nineteenth century.

The development of the Royal Institution reflected quite precisely these broad changes. For much of the nineteenth century it had possessed the best-equipped laboratory in England and one of the best in Europe. By the end of the century this was far from the case and it became clear that if the Royal Institution was to maintain its reputation as a major research laboratory it would have to change its structure. Scientific research at the Royal Institution was given a massive boost in the 1890s when the industrial chemist Ludwig Mond (1839-1909) endowed the Davy-Faraday Research Laboratory. Number 20 Albemarle Street was purchased and converted into a large modern laboratory that extended the Royal Institution's facilities beyond the two or three basement rooms that had been used hitherto. The Davy-Faraday Research Laboratory was opened by Edward, Prince of Wales, (18411910) in 1896 with Dewar and Rayleigh as its joint first Directors. A year and a half after its opening Dewar finally achieved his goal when on 10 May 1898 he first liquefied hydrogen.

However, by the end of the Great War, with Dewar in his late seventies and refusing to retire, and with the rest of the Royal Institution's leadership of a similar age, the laboratory had become quite moribund. Dewar's death in 1923 was followed by the appointment of the 
Nobel Prize winner William Henry Bragg (1862-1942) in his place. Bragg had been educated at the University of Cambridge and had then taught mathematics and physics at the University of Adelaide in South Australia where his son, William Lawrence Bragg (18901971), was born. He had commenced working on radioactivity and X-rays by 1904, and was critical of the theory of X-rays proposed by J.J. Thomson (1856-1940). So significant was Bragg's work that in 1909 he returned to England as Professor of Physics at the University of Leeds. In 1912 he and Lawrence (by now a research student at the Cavendish Laboratory, Cambridge), worked out how to determine the structure of crystals using their X-ray diffraction patterns. For this work they jointly received the Nobel Prize for Physics in 1915; Lawrence Bragg, at the age of twenty five, remains the youngest Nobel Prize winner ever.

Under Bragg the Royal Institution and the Davy-Faraday Research Laboratory both took on new vitality, restoring the place of the Royal Institution at the centre of science communication and making the laboratory the most important X-ray crystallography laboratory in the world. Bragg changed the modus operandi of the Davy-Faraday Research Laboratory, believing in the value of directed collaborative research rather than letting individual scientists pursue their own particular interests. Thus, all of the scientists working in the laboratory from 1923 onwards collectively concentrated on understanding the structure of organic molecules. The work of Bragg and his group was particularly crucial for the development of molecular biology, which depended on understanding the atomic structure of crystals of organic materials which could be obtained only by analysis of their X-ray diffraction patterns.

The formidable team of researchers on crystallography that Bragg built up included John Desmond Bernal (1901-1971), William Thomas Astbury (1898-1961), and, briefly, the only British woman ever to win (in 1964) the Nobel Prize for Chemistry, Dorothy Hodgkin (1910-1994). Another member of Bragg's team, Kathleen Lonsdale (1903-1971), the first woman to be elected (in 1945) a Fellow of the Royal Society, worked in the 1920s on the theory of space groups to help determine where possibilities of molecular symmetry might occur. A century or so after Faraday had discovered benzene in the Royal Institution, Lonsdale demonstrated, for the first time, that its structure was hexagonal and planar, and she also calculated its precise dimensions. The team structure of the Davy-Faraday Research Laboratory in the 1920 s proved to be an early example of what has since become the standard pattern for undertaking scientific research.

The group at the Royal Institution formed the core of what can be identified as the British school of crystallography and later of molecular biology. Another prominent member 
of this school was, of course, Lawrence Bragg. He served in Flanders with the sound-ranging units during the Great War and after demobilization succeeded Ernest Rutherford (18711937) as Professor of Physics at the University of Manchester. In an informal agreement between father and son, they decided that William would concentrate on the structure of organic molecules while Lawrence would work on inorganic materials, particularly minerals. Lawrence remained at Manchester until the late 1930s when after a brief period directing the National Physical Laboratory he was appointed Director of the Cavendish Laboratory, again succeeding Rutherford. There he too, following the death of his father in 1942, turned his attention to organic molecules with his group, which included Max Perutz (1914-2002), John Kendrew (1917-1997), Francis Crick (1916-2004), and James Watson (b.1928). In 1953 the latter two scientists, working under Bragg's direction and using the techniques he had pioneered, proposed the double helical structure for DNA - one of the key scientific discoveries of the twentieth century as it underpinned the development of molecular biology. Bragg wrote the placatory preface to Watson's somewhat biased view of the discovery in his book, The Double Helix (1968).

Following the elder Bragg's death in 1942, there was a period when there were three Directors of the Davy-Faraday Research Laboratory, Henry Dale (1875-1968), Eric Rideal (1890-1974), and E.N. da C. Andrade (1887-1971). Each held the post for less than four years. Dale, as President of the Royal Society and Chairman of the War Cabinet's Scientific Advisory Committee (which William Bragg had helped to establish), was fully occupied during his period of office. Lonsdale, despite spending a month in 1943 in Holloway Prison for refusing, as a Quaker and Conscientious Objector, to register as a Civil Defence Worker, kept research going.

Following Andrade's forced resignation in mid-1952, Lawrence Bragg took over at the start of 1954. Research in the Royal Institution returned to X-ray crystallography concentrating on the structure of proteins, undertaken by Perutz and Kendrew (who held joint appointments at the Royal Institution and the University of Cambridge) for which they received the Nobel Prize for Chemistry in 1962. In the first half of the 1960s work in the laboratory turned to the structure of enzymes. This was undertaken by a group headed by David Phillips (1924-1999) that included Louise Johnson (1940-2012). This project required the first computer to be installed in the Royal Institution. Paid for by the Medical Research Council, the Elliott 803 was installed in 1963, and helped Phillips and his group to make the first determination of the structure of an enzyme, lysozyme (figure 5). It is little wonder then 
that Dale later wrote "It is cheering to recognise the extent to which research in "Molecular Biology", first at Cambridge and now at Oxford, will have been pioneered from the R.I."

On Bragg's retirement in 1966, George Porter (1920-2002) was appointed Director, a position he held until 1985 when he became President of the Royal Society. Research at the Royal Institution switched to investigating high-speed chemical reactions using photochemical methods, with Porter and his group being able to get down to the picosecond $\left(10^{-12}\right.$ second) level. Under Porter, the heritage of the Royal Institution received considerable attention. A new archive reading room and vault was provided and a museum devoted entirely to Faraday and his work was built next to his magnetic laboratory which had survived intact from the 1850s. This museum was opened to the public in 1973 by Her Majesty, Queen Elizabeth (b.1926), the first time that a reigning monarch had visited the Royal Institution (figure 6).

With the exception of Faraday's laboratory, which was unaltered, all the heritage displays at the Royal Institution were completely reinterpreted in the period 2003-2008 and formally opened by the Queen on 28 May 2008. The display now tells the story of the role that the Royal Institution has played in science for more than two centuries and how this has affected the daily lives of every individual (figure 7). Unlike the vast majority of museums devoted to science, where the objects were created and used elsewhere, visitors to the Royal Institution can experience them in the very building where they have been always been located. Not many other sites of scientific heritage can say the same.

\section{Further reading}

Ruth Barton, "John Tyndall, pantheist: A rereading of the Belfast address," Osiris, 1987, 3: 111-134.

Morris Berman, Social Change and Scientific Organization: The Royal Institution 1799-1844 (London, 1978).

Geoffrey Cantor, "Thomas Young's Lectures at the Royal Institution," Notes and Records of the Royal Society of London, 1970, 25: 87-112. 
Geoffrey Cantor, Michael Faraday: Sandemanian and Scientist. A Study of Science and

Religion in the Nineteenth Century (London: Macmillan, 1991).

Ursula DeYoung, A Vision of Modern Science: John Tyndall and the Role of the Scientist in Victorian Culture (Basingstoke, 2011).

Sophie Forgan, The Royal Institution of Great Britain, 1840-1873 (unpublished PhD Thesis, University of London, 1977).

J.Z. Fullmer, Young Humphry Davy: the Making of an Experimental Chemist (Philadelphia, 2000).

Jan Golinski, Science as Public Culture: Chemistry and Enlightenment in Britain, 1760-1820 (Cambridge, 1992).

David Gooding, Experiment and the Making of Meaning: Human Agency in Scientific Observation and Experiment (Dordrecht, 1990).

David Gooding and Frank A.J.L. James, eds., Faraday Rediscovered: Essays on the Life and Work of Michael Faraday, 1791-1867 (London, 1985).

David Knight, Humphry Davy: Science and Power (Oxford, 1992; Second Edition, Cambridge, 1996).

Roland Jackson, "John Tyndall and the Early History of Diamagnetism," Annals of Science, forthcoming.

Frank A.J.L. James, The Correspondence of Michael Faraday (6 volumes, London, 19912012).

Frank A.J.L. James, ed., 'The Common Purposes of Life': Science and Society at the Royal Institution of Great Britain (Aldershot, 2002), 
Frank A.J.L. James, "How Big is a Hole?: The Problems of the Practical Application of Science in the Invention of the Miners' Safety Lamp by Humphry Davy and George Stephenson in Late Regency England," Transactions of the Newcomen Society, 2005, 75 : 175-227.

Frank A.J.L. James, "Presidential address. The Janus face of modernity: Michael Faraday in the twentieth century," British Journal for the History of Science, 2008, 41: 477-516.

Frank A.J.L. James, Michael Faraday: A Very Short Introduction (Oxford, 2010).

Frank A.J.L. James, ed., Michael Faraday, The Chemical History of a Candle.

$\underline{\text { Sesquicentenary Edition With a fracsimile reproduction of Faraday's manuscript lecture notes }}$ from Royal Institution MS F4 J21 (Oxford, 2011).

Frank A.J.L. James and Anthony Peers, "Constructing Space for Science at the Royal Institution of Great Britain,” Physics in Perspective, 2007, 9: 130-85.

John Jenkin, William and Lawrence Bragg, Father and Son: The Most Extraordinary Collaboration in Science (Oxford, 2008).

David Phillips and John M. Thomas, eds., Selections and Reflections: The Legacy of Sir Lawrence Bragg (Northwood, 1990).

Sydney Ross, "Faraday consults the scholars: The origins of the terms of electrochemistry," Notes and Records of the Royal Society of London, 1961, 16: 187-220.

John Rowlinson, Sir James Dewar, 1842-1923: A Ruthless Chemist (Farnham, 2012).

Web resource:

http://www.rigb.org/our-history 
Illustration captions:

All images are reproduced courtesy of the Royal Institution of Great Britain.

Figure 1. Watercolour by Thomas Shepherd of Royal Institution's facade built in late 1830s and designed by Lewis Vulliamy.

Figure 2. Oil painting by Henry Pickersgill (after Thomas Lawrence), 1831, of Humphry Davy with miners' safety lamp.

Figure 3. Hand coloured etching by James Gillray showing Thomas Garnett lecturing on laughing gas with Humphry Davy in 1801 (published 1802).

Figure 4. Faraday's electro-magnetic induction ring, first used on 29 August 1831,

Figure 5. Model of lysozyme,c.1965.

Figure 6. George Porter demonstrating picosecond flash photolysis to HM the Queen, 5 February 1973.

Figure 7. Current display, 2008. 